\title{
KARAKTERISASI BAMBU LAMINASI SEBAGAI BAHAN PEMBANGUNAN KAPAL PERIKANAN*)
}

\author{
sebagai solusi mengatasi sumber daya kayu yang semakin langka
}

\author{
oleh : \\ AKHMAD BASUKI WIDODO \\ Jurusan Teknik Perkapalan \\ Fakultas Teknik dan Ilmu Kelautan \\ Universitas Hang Tuah \\ SUARABAYA
}

\section{Ringkasan :}

Penggunaan bambu dibidang konstruksi sampai saat ini masih sangat terbatas dan hanya digunakan pada struktur ringan. Pengembangan penggunaan bambu dibidang struktur, khususnya dibidang pembangunan kapal, dapat dikatakan masih belum tersentuh. Dengan adanya teknologi laminasi dan dengan perlakuan tertentu, diharapkan pemanfaatan bambu dapat diperluas pada penggunaan struktur dan dibidang perkapalan, khususnya kapal non baja. Dari hasil penelitian dan pengujian ditunjukkan bahwa komposit kayu jati dan/atau bambu betung mempunyai sifat fisis dan sifat mekanis yang lebih baik dibandingkan dengan kayu jati yang selama ini digunakan sebagai bahan pembangunan kapal kayu. Sebagai bahan pembangunan kapal kayu, komposit bambu mempunyai kerapatan (density) yang lebih tinggi dibandingkan dengan kayu jati solid dan komposit lainnya. Kerapatan bahan sangat berpengaruh terhadap berat kapal yang akhirnya akan berpengaruh pula terhadap ruang muat (palka), kecepatan kapal dan kebutuhan bahan bakar. Tetapi komposit kayu jati dan bamboo betung dengan jumlah lapisan 5 dengan komposisi kayu jati-nya 2/3 dari keseluruhan, mempunyai kerapatan yang lebih rendah dibandingkan dengan kayu jatin solid.

Secara keseluruhan, sifat mekanis komposit kayu jati dan bambu betung lebih baik dibandingkan dengan kayu jati solid, rata-rata kenaikan kekuatannya mencapai $40 \%$.

Pengaruh ruas bambu terhadap kekuatan bending dan tarik (tension) dibandingkan tanpa ruas, kekuatannya menurun sekitar 10 persen tergantung dari jumlah lapisan dan jenis kayu. Tetapi dengan jumlah lapisan dan jenis kayu yang sama, maka komposit bambu dengan kayu jati mempunyai tingkat penurunan yang paling kecil $( \pm 7,35$ persen).

Ketahanan komposit kayu jati dan/atau bambu betung terhadap beban bergerak, komposit bambu mempunyai ketahanan terhadap beban dinamis yang paling baik. Hal ini ditunjukkan dengan adanya kekuatan sisa (residual strength) yang masih tinggi.

Sesuai dengan regulasi Biro Klasifikasi Indonesia (BKI) untuk Ketentuan Kapal Kayu, maka komposit kayu jati dan bambu betung memenuhi persyaratan bahan untuk bahan pembangunan kapal non baja.

Disain kapal dengan menggunakan bahan utama komposit bambu dengan ukuran 5 gross tonnage (GT) dengan ukuran utama (principal dimension) panjang secara keseluruhan $($ LOA $)=9.47$ meter, lebar kapal $(\mathrm{B})=2.80$ meter dan tinggi badan kapal (D) $=1.20$ meter. Kecepatan 8.0 knot dengan waktu operasi (endurance) selama 3 hari dengan 4 personil. Mesin yang digunakan $52 \mathrm{~kW}$ dengan ruang muat ikan sebesar $4.00 \mathrm{~m} 3$.

\section{Kata Kunci : Laminasi Bambu, Ruas Bambu, Beban Dinamis, Kelelahan Material}

\section{PENDAHULUAN.}

Pemanfaatan kekayaan bahari sampai saat ini masih sangat rendah dan hanya dilakukan oleh para nelayan disekitar pesisir pantai saja. Salah satu kendalanya adalah keterbatasan dalam penyediaan sarana dan prasarana penangkapan ikan, yaitu kapal yang mampu melayari sampai wilayah ZEE (Zone Eksklusive Ekonomi). Keterbatasan tersebut akibat terlalu mahalnya material untuk membangun kapal nelayan yang umumnya terbuat dari kayu. Sedangkan kayu semakin hari dirasakan semakin susah didapat dan harganya tinggi. Dengan diketemukan material alternatif, yaitu bambu laminasi, yang mempunyai sifat sama atau hampir sama dengan material kayu yang selama ini dikenal. Diharapkan bambu laminasi dapat menggantikan material kayu yang selama ini digunakan sebagai bahan utama untuk pembangunan kapal kayu. 
Material yang digunakan pada struktur kapal harus mampu menahan beban bergerak (dynamic loading), karena gaya yang bekerja pada struktur kapal pada umumnya adalah beban dinamis. Salah satu kelemahan dari material pada umumnya adalah apabila menerima beban dinamis dalam jangka waktu yang relatif lama adalah kekuatan material tersebut akan menurun, tidak terkecuali kayu. Akan tetapi penurunan kekuatan pada kayu akibat beban dinamis tersebut tidak sebesar penurunan pada baja (Faherty, 1999). Mengingat bahwa kekuatan material pembentuk kapal harus mendapat perhatian yang lebih, maka material tersebut harus diketahui karakternya terhadap beban dinamis. Dengan diketahuinya karakter kelelahan (fatigue characterization) dari material komposit bambu, maka dapat pula dirancang material yang cocok digunakan pada bagian-bagian utama konstruksi kapal, baik ketebalan, lebar, dan panjangnya yang cocok untuk produksi kapal perikanan. Dari perencanaan berat konstruksi kapal, perbandingan antara muatan dengan berat lambung sebesar mungkin dengan stabilitas yang baik dan perencanaan optimum. Kita ketahui bahwa bambu mempunyai perbandingan kekuatan dengan berat yang baik dibandingkan dengan material lain. Selain itu dengan mengetahui sifat dan karakter kelelahan material akan diketahui pula umur pakai (life time) dari material tersebut.

Didapatkannya material substitusi yang mempunyai sifat dan karakter yang sama sehingga mampu menggantikan material kayu yang selama ini digunakan pada struktur kapal kayu. Hal ini untuk mengantisipasi kebutuhan kayu yang semakin meningkat dengan meningkatnya jumlah penduduk. Demikian juga kebutuhan kayu untuk pembangunan kapal nelayan, dengan semakin bertambahnya nelayan akan semakin banyak pula kebutuhan kapal kayu yang digunakan untuk menangkap ikan. Hal ini akan mengakibatkan kebutuhan ikan sebagai bahan pembangunan kapal kayu juga akan semakin meningkat.

Walaupun bambu banyak mempunyai beberapa keunggulan dibidang sifat fisis dan sifat mekanis, maka yang perlu diperhatikan adalah ketahanan bambu terhadap seranggan serangga atau binatang laut. Bambu atau kayu yang tidak diawetkan dan digunakan dilaut atau diair tawar cepat menjadi rusak karena dirusak atau diserang oleh organisma perusak kayu. Penyerangan organisma perusak ini, terutama yang berupa binatang laut dapat berlangsung dengan sangat cepat, sehingga dalam waktu yang relatif pendek bambu atau kayu sebagai bahan pembuatan kapal akan menjadi rusak dan hancur. Ada beberapa usaha untuk mencegah terhadap serangan organisma perusak atau binatang laut, baik berupa usaha pencegahan atau dengan pengawetan. Pada daerah tropis seperti yang ada di Indonesia, banyak sekali jenis organisma perusak dan dapat berkembang dengan cepat serta dijumpai sepanjang tahun. Tetapi dengan beberapa cara pemberian treatment, bambu mapu bertahan lama, bahkan sampai 20 tahun bambu mampu bertahan terhadap serangan serangga ataupun pelapukan.

Bahan baku pembuatan kapal kayu harus mempunyai sifat mekanis yang tinggi tetapi mempunyai berat yang ringan serta mempunyai keelastisitasan yang baik. Hal ini berhubungan dengan kecepatan kapal yang berhubungan dengan kebutuhan bahan bakar dan ruang muat atau palka tempat ikan. Sedang keelastisitasan berhubungan erat dengan proses pembentukan badan kapal.

Industri kapal kayu merupakan suatu kelompok usaha tradisional yang mencerminkan penyelesaian kreatif para pengrajin lokal dalam mengembangkan bentuk kapal kayu sebagai suatu alat penangkap ikan dan alat transportasi manusia dan barang antar pulau di seluruh wilayah Indonesia.

\section{KARAKTERISASI KONSTRUSKI KAPAL PERIKANAN.}

Dalam bangunan kapal kayu pada dasarnya komponen utamanya dapat digolongkan dalam kesamaan bentuk seperti lurus dan lengkung dan kesamaan konstruksi seperti bentuk papan dan balok (Rosyid, 2000). Klasifikisasi komponen utama kapal tersebut dapat dilihat pada tabel berikut ini. 
Tabel. Klasifikasi Komponen Utama Kapal.

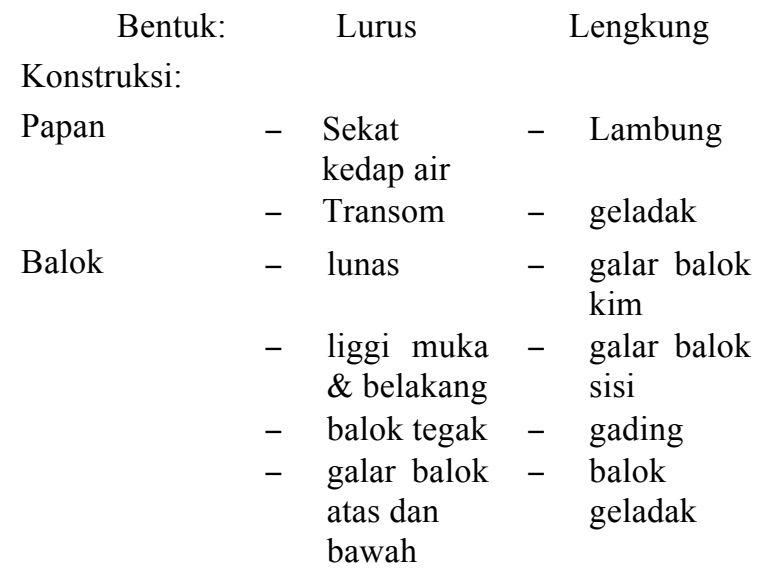

Frame (gading), rib (penguat), keel (lunas), stem (linggi) dan deck beam (balok geladak) merupakan komponen struktur utama kapal kayu yang dapat dibuat dengan konstruksi laminasi. Alasan penggunaan konstruksi laminasi pada komponenkomponen tersebut adalah kemudahan membentuk komponen kapal tersebut sangat dimungkinkan. Pada umumnya pembuatan komponen yang mempunyai bentuk lengkung seperti untuk frame adalah dengan cara pemanasan (steaming), atau mencari bentuk dari pohon yang sesuai dengan bentuk frame, atau membentuk dari pola penggergajian dari material yang ada (anonim, 1985). Disamping kemudahan membentuk komponen kapal dengan konstruksi laminasi, keuntungan lain dari konstruksi laminasi tersebut adalah : (a). Mempunyai kekuatan yang tinggi walaupun pembentuk laminasi tersebut mempunyai cacat kayu seperti mata kayu, (b). Curved laminasi yang terbuat dari beberapa potongan papan yang tipis dapat menghilang internal stress dalam komponen kapal tersebut dan (c). Mempunyai nilai ekonomi yang tinggi, karena dapat menggunakan papan kayu yang mempunyai dimensi kecil (Williamson, 2002; Chugg, 1964; US Forest Products, 1987).

Bentuk lurus seperti lunas, lantai kapal, kulit, sedangkan untuk bentuk lengkung terjadi pada gading-gading (frame), linggi (stem). Komponen utama kapal kayu, mempunyai sifat yang berbeda antara komponen yang satu dengan komponen lainnya. Komponen kapal kayu ada yang memerlukan kelenturan yang tinggi dimana pada bagian kapal memerlukan bentuk yang streamline seperti pada lambung.

Fakultas Teknik Universitas Pattimura,

ISSN : 2620-3995
Tetapi pada bagian lain memerlukan kekakuan yang tinggi seperti pada gading-gading dan balok gelagar, pada umumnya pada bagian ini memerlukan kekakuan (stifness) yang tinggi (Anonim, 1985).

Sesuai dengan Peraturan dan Konstruksi Kapal Kayu BKI, (1996) dan menurut Karnasudirdja, (1979), untuk konstruksi lunas, linggi, gadinggading, balok buritan harus menggunakan kayu dengan berat jenis atau kerapatan minimum 700 $\mathrm{kg} / \mathrm{m} 3$. Apabila bagian konstruksi gading-gading menggunakan konstruksi laminasi, pada bagian tengah dari konstruksi laminasi dapat menggunakan kayu dengan kerapatan yang lebih rendah hingga $450 \mathrm{~kg} / \mathrm{m} 3$ dan tebal keseluruhan dari kayu sisipan tersebut tidak boleh melebihi $30 \%$ dari total ketebalan dari gading-gading. Untuk konstruksi kulit kapal (lambung), balok geladak, penumpu geladak diperkenankan kayu dengan kerapatan $560 \mathrm{~kg} / \mathrm{cm} 3$. Dan untuk geladak dan galar bilga kayu yang digunakan minimum mempunyai kerapatan $450 \mathrm{~kg} / \mathrm{cm} 2$.

Apabila dalam konstruksi kapal kayu tersebut menggunakan kayu dengan spesifikasi yang lebih ringan, maka ukuran konstruksi kapal kayu tersebut dapat diperbesar sesuai dengan perbandingan kekuatan dan kerapatannya. Demikian juga apabila konstruksi kapal tersebut menggunakan spesifikasi yang lebih baik, maka ukuran konstruksi atau komponen kapal tersebut dapat diperkecil (BKI, 1996). Dalam konstruksi kapal kayu tersebut, apabila diijinkan untuk menggunakan kayu laminasi dan ukurannya dapat diperkecil sesuai dengan aturan dan tidak melebihi dari $30 \%$ dari konstruksi awalnya.

Konstruksi kapal kayu pada umumnya terdiri dari konstruksi utama dan konstruksi pendukung. Pada konstruksi utama terdiri gading-gading (frame), balok geladak (deck beam), kulit (shell), lantai (deck), linggi (front keel), lunas (keel). Sedangkan konstruksi penunjang meliputi dinding rumah (deck house), dudukan mesin (engine bed), senta (bilge stringer), pisang-pisang (bumper). Penampang melintang konstruksi utama kapal kayu dapat dilihat pada gambar berikut ini. 


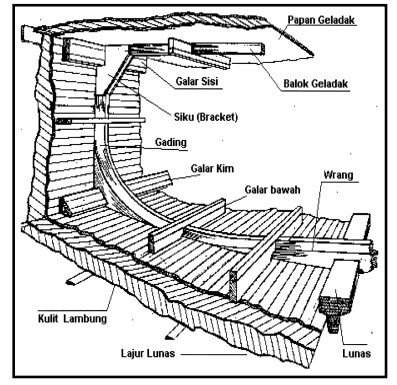

Penampang Melintang Kapal dengan beberapa bagian Konstruksi Utama

Karena sifatnya yang baik, dimana kayu jati mempunyai density yang tidak terlalu besar, tetapi kekuatannya melebihi jenis kayu lain yang mempunyai berat jenis (density) yang lebih besar, maka kayu jati cocok digunakan pada konstruksi ko mponen kapal kayu. Kayu jati dapat digunakan disemua komponen kapal kayu seperti untuk lunas, keel, frame (gading-gading), deck, transom dan deck house (Martawidjaja, 1978).

\section{SIFAT BAMBU LAMINASI.}

\section{Sifat Fisis.}

\subsection{Kerapatan (density).}

Sifat bahan yang penting untuk pembangunan kapal kayu yang dilakukan pengujian adalah pengukuran kerapatan (density) material laminasi kayu-bambu. Dari hasil pengukuran diperoleh hasil bahwa laminasi bambu mempunyai kerapatan yang lebih tinggi dibandingkan dengan kayu solid atau kayu laminasi, baik kayu jati, meranti merah maupun mahoni. Tetapi perbedaan kerapatan tersebut setelah dianalisa dengan Rancangan Acak Lengkap ternyata tidak berbeda nyata, baik pada tingkat $95 \%$ maupun $99 \%$. Untuk lebih jelasnya dapat dilihat pada gambar berikut ini.

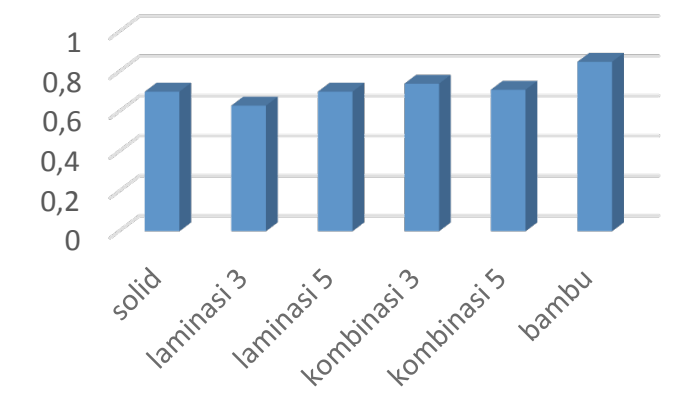

Kerapatan (density).

Fakultas Teknik Universitas Pattimura,

\subsection{Kembang Susut.}

Sifat bahan terakhir yang dilakukan pengujian atau pengukuran adalah sifat kembang susut bahan pada arah lebar. Pada arahnya ini perlu diketahui karena akan berpengaruh terhadap kekedapan lambung kapal yang diakibatkan kadaan basah dan kering pada saat kapal dalam muatan penuh dan kosong atau dalam keadaan kena ombak dan tidak. Sehingga perubahan basah ke kering atau sebaliknya dapat menimbulkan celah pada sambungan dibagian lambung kapal, sehingga bahan yang mempunyai kembang susut besar akan menimbulkan celah yang besar dan akan terjadi kebocoran.

Dari hasil yang diperoleh bahwa laminasi bambu dan laminasi bambu mempunyai penyusutan yang lebih kecil dibandingkan dengan kayu solid atau laminasi kayu, baik kayu jati, meranti merah maupun mahoni.

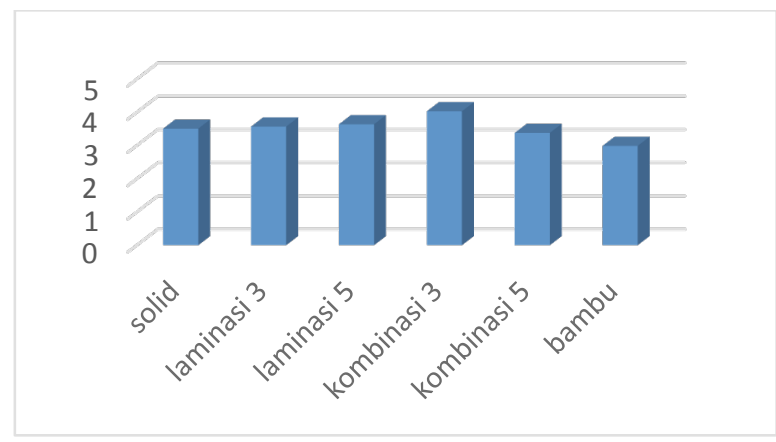

Penyusutan.

\section{Sifat Mekanis.}

\subsection{Bending Statis}

Dari hasil pengujian kekuatan lentur, dapat dilihat bahwa bambu dan laminasi bambu mempunyai kekuatan yang tinggi dibandingkan dengan kayu dan laminasi kayu. Karena bambu mempunyai elatisitas yang lebih tinggi dibandingkan dengan kayu dan bahkan dengan baja, maka secara nyata laminasi bambu mempunyai kekuatan lentur yang tinggi.

Untuk lebih jelasnya perbedaan kekuatan lentur antara kayu, laminasi kayu, kombinasi kayubambu dan laminasi bambu dapat dilihat pada gambar berikut ini.
ISSN : 2620-3995

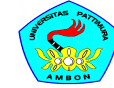

: $2620-3995$ 


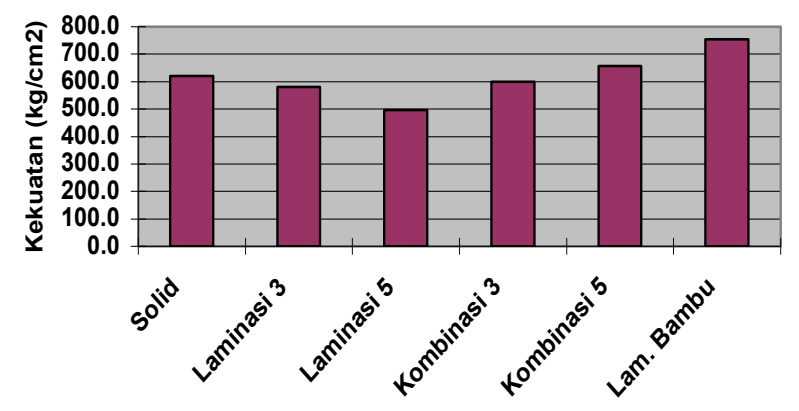

Kekuatan Lentur Statik (Bending).

\subsection{Kekuatan Tarik (Tension).}

Untuk pengujian kekuatan tarik menunjukkan hasil yang sama dengan kekuatan lentur, dimana laminasi/laminasi yang mengandung bambu mempunyai kekuatan tarik yang lebih tinggi dibandingkan dengan laminasi/laminasi kayu.

Hal ini dikarenakan sifat dari serat bambu yang mempunyai kekuatan tarik yang lebih baik dibandingkan dengan kekuatan tarik serta kayu. Sedangkan kombinasi bambu dengan kayu, tidak mempunyai perbedaan yang nyata. Hal ini disebabkan pada saat kekuatan tarik kayu memcapai maksimum, sedangkan bambu belum mencapai kekuatan maksimum, maka gaya yang bekerja hanya tertumpu pada kekuatan tarik bambu. Dari hasil analisa, menunjukkan bahwa kekuatan tarik antara kayu, laminasi kayu dan laminasi kayu-bambu serta laminasi bambu mempunyai perbedaan yang tidak begitu nyata. Untuk lebih jelasnya perbedaan kekuatan tarik dari laminasi kayu-bambu dapat dilihat pada gambar berikut ini.

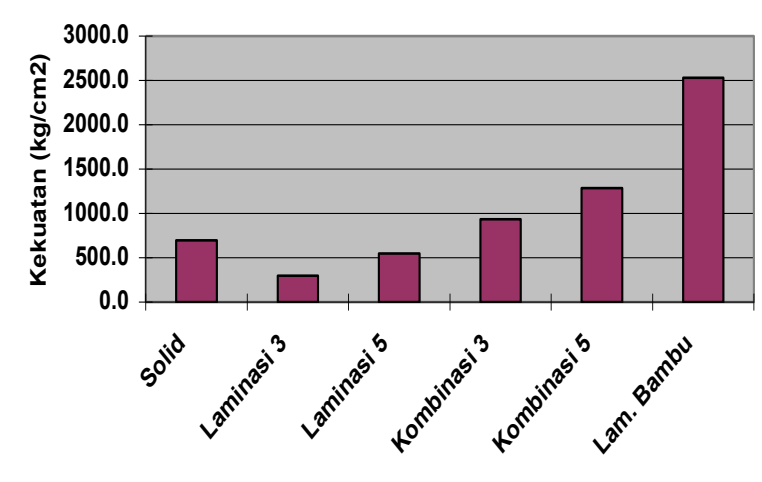

Kekuatan Tarik (Tension).

Sedangkan kerusakan yang terjadi setelah dilakukan uji tarik seperti pada gambar berikut ini.

Fakultas Teknik Universitas Pattimura, ISSN : 2620-3995

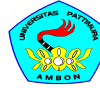

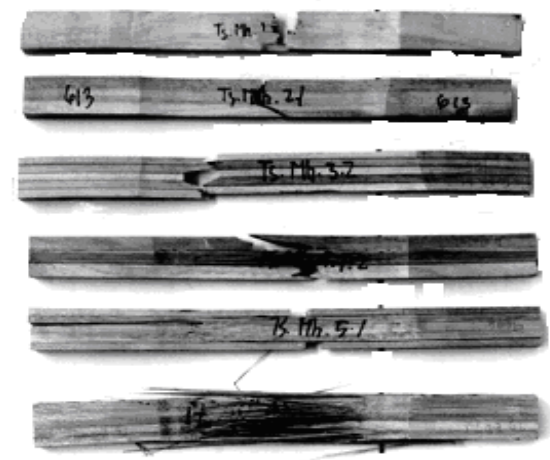

\subsection{Kekuatan Pukul (Impact).}

Sifat bahan lain yang perlu untuk diketahui sebagai persyaratan untuk kapal kayu adalah sifat kekuatan pukul (impact bending). Dari hasil pengujian yang dilakukan, bahwa kekuatan pukul material laminasi kayu-bambu dan laminasi bambu mempunyai ketahanan pukul yang lebih baik dibandingkan dengan kayu solid atau laminasi kayu. Serat bambu mempunyai kekuatan yang lebih baik dibandingkan dengan kekuatan serat kayu.

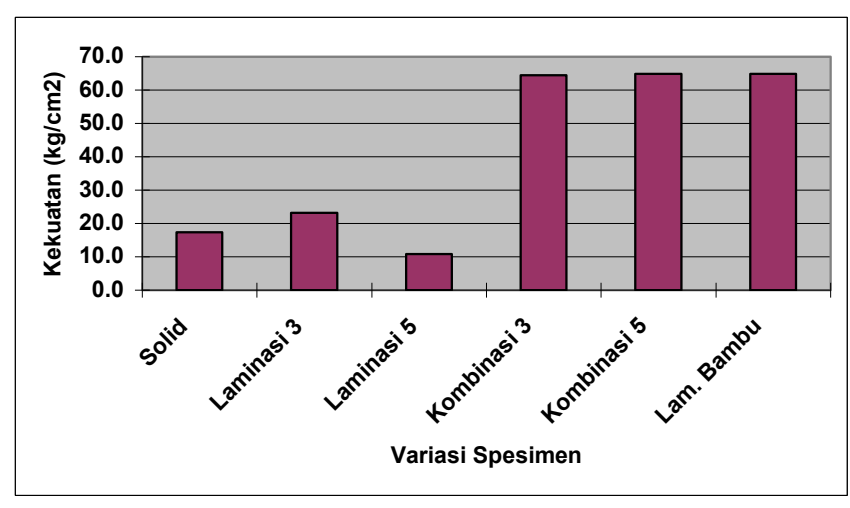

Kuat Pukul Laminasi Bambu.

\section{Pengaruh Ruas Bambu Terhadap Kekuatan Bambu.}

Ruas mempunyai pengaruh terhadap keteguhan lentur statik, baik sampai batas patah (MOR) maupun sampai batas keelastisitasan (MOE). Penurunan kekuatan ini disebabkan adanya arah serat yang tidak seragam atau searah pada ruas. Sebagian serat lurus membentuk batang bambu dan sebagian lainnya berbelok membentuk ruas dan kembali lurus bersama-sama membentuk batang bambu. Serat yang berbelok membentuk ruas itulah yang mempunyai sifat lemah terhadap kekuatan bambu. 


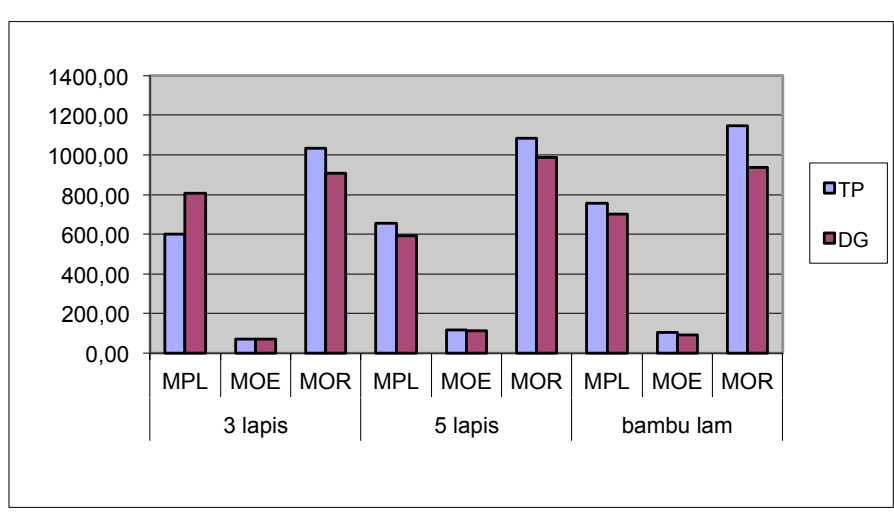

Perbandingan Kuat Tarik Laminasi Bambu Tanpa Ruas dan Dengan Ruas.

Penurunan kekuatan laminasi bambu akibat adanya ruas berkisar antara $4.35 \%$ hingga 18.33 persen. Pada penelitian ini, letak dan pengaturan ruas pada struktur laminasi tidak diperhatikan, karena jarak sambungan atau ruas dalam struktur laminasi adalah 20 kali tebal laminasi yang membentuknya.

Dari hasil analisa dengan menggunakan Analisa Covarian Rancangan Acak Lengkap Vaktoraial 2 x 3 menunjukkan dari hasil perhitungan menunjukkan bahwa F-hitung lebih besar dibandingkan dengan F-tabel. Hal ini menunjukkan bahwa pengaruh ruas bambu terhadap kekuatan bending, baik untuk MPL, MOE dan MOR mempunyai pengaruh yang sangat nyata, baik pada tingkat kepercayaan 95 persen maupun 99 persen.

Tetapi untuk pengaruh ruas bambu terhadap jumlah lapisan (number of layer) mempunyai pengaruh terhadap kekuatan bending (MPL, MOR, MOE), tetapi sangat kecil dan tidak significan.

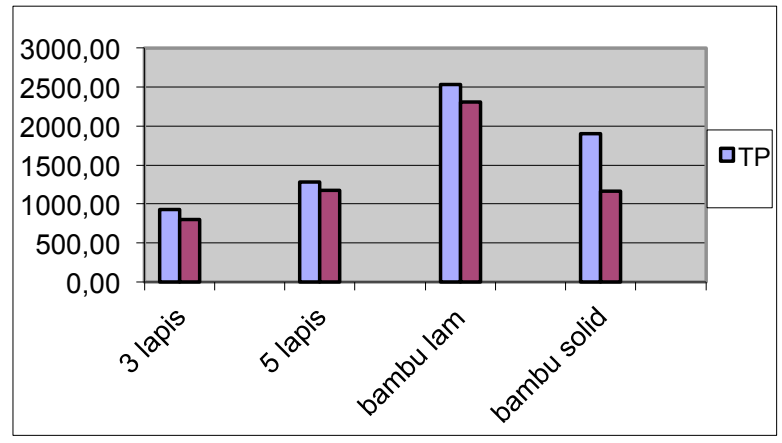

Perbandingan Kuat Tarik (Tension) Laminasi bambu Tanpa Ruas dan Dengan Ruas
Dari hasil analisa dengan menggunakan Analisa Covarian Rancangan Acak Lengkap Vaktoraial 2 x 4 menunjukkan dari hasil perhitungan menunjukkan bahwa F-hitung lebih besar dibandingkan dengan F-tabel. Hal ini menunjukkan bahwa pengaruh ruas bambu terhadap kekuatan tarik mempunyai pengaruh yang sangat nyata, baik pada tingkat kepercayaan 95 persen maupun 99 persen. Tetapi untuk pengaruh ruas bambu terhadap jumlah lapisan (number of layer) mempunyai pengaruh terhadap kekuatan tarik (tension), tetapi sangat kecil dan tidak significan.

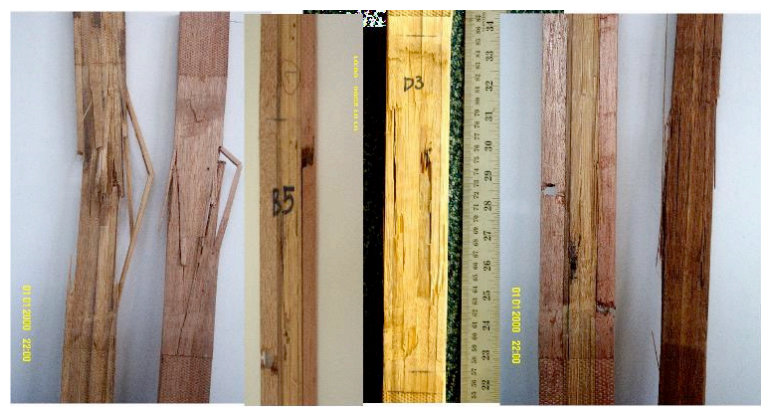

Kerusakan akibat Uji Tarik pada Laminasi bambu dengan Ruas dan Tanpa Ruas.

Hal ini menunjukkan bahwa jumlah laminasi dan penempatan ruas pada struktur laminasi mempunyai pengaruh yang nyata.

Pada struktur laminasi laminasi bambu penurunan kekuatan tarik paling besar $10 \%$. Sedangkan pada bambu bukan laminasi penurunan kekuatan tariknya mengalami penurunan kekuatan hampir $40 \%$.

\section{Pengaruh Beban Dinamis (Dynamic Loading) terhadap Kekuatan Bambu Laminasi.}

Dari pengujian awal dengan beban atau frekwensi dikurangi menjadi $60 \%$ dari kekuatan statik, diperoleh hasil bahwa laminasi bambu mempunyai kelelahan atau endurance limit yang lebih baik dibandingkan dengan laminasi kayu, laminasi kayu bambu maupun kayu solid. Hal ini ditunjukkan pada kerusakan material laminasi bambu terjadi pada siklus beban yang lebih tinggi, yaitu sekitar $10^{3}$ kali penerimaan beban. Sedangkan contoh uji lainnya dibawah siklus beban tersebut. Demikian juga makin 
tinggi jumlah lapisan akan semakin lama siklus penerimaan beban.

Kuat tarik dalam Newton (N) yang dibagi dengan luas penampang ( $\mathrm{mm} 2)$ spesimen uji pada bagian yang paling tipis. Sedangkan defleksi (elongation) adalah perebahan bentuk pada spesimen uji sampai pada batas plastis. Data yang disajikan pada tabel tersebut merupakan rata-rata dari 3 (tiga) spesimen uji yang dilakukan sebagai ulangan dalam penelitian ini.

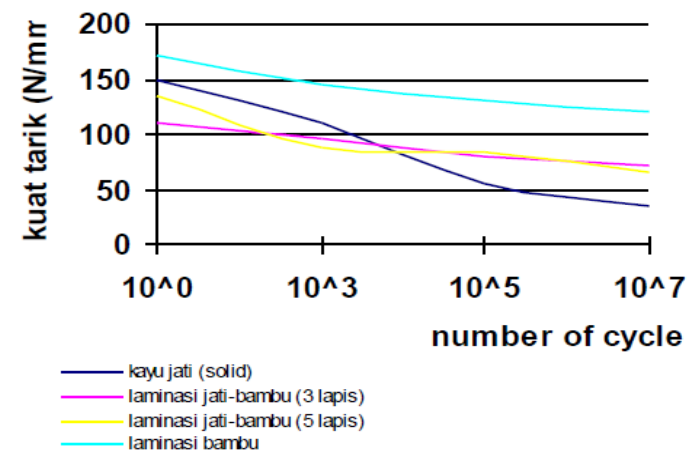

Grafik Uji Kelelahan Laminasi bambu.

\section{KESIMPULAN.}

Dari hasil karakterisasi kapal perikanan dan sifat bambu laminasi dapat disimpulkan sebagai berikut :

- Laminasi Bambu mempunyai kerapatan (density) yang lebih besar (15.71\%) dibandingkan dengan kayu jati. Tetapi dengan kerapatan yang lebih besar, bukan berarti bahwa laminasi bambu betung tidak dapat digunakan sebagai pengganti kayu jati. Mengacu pada regulasi penggunaan material pada pembangunan kapal kayu tersebut laminasi bambu masih ada kemungkinan digunakan sebagai bahan pembangunan kapal kayu dengan melihat sifat mekanik dan sifat lainnya.

Kembang susut arah lebar maupun volume laminasi bambu lebih besar dibandingkan dengan kayu jati, tetapi perbedaan tersebut tidak menunjukkan perbedaan yang nyata. Sehingga ditinjau dari penyusutannya, laminasi bambu dapat digunakan sebagai bahan pembangunan kapal kayu.

- Laminasi Bambu mempunyai kelenturan bending statik sampai batas proporsi (MPL) lebih tinggi $(76.26 \%)$ dibandingkan dengan kayu jati. Sedangkan untuk kekuatan bending statik sampai MOE dan MOR, laminasi bambu betung lebih tinggi masing $33.36 \%$ dan $52.32 \%$ dibandingkan dengan kayu jati.

Laminasi bambu mempunyai kuat tarik yang jauh lebih tinggi hingga mencapai 2 kali lipat (263.64\%) dibandingkan dengan laminasi kayu jati. Kuat tarik bambu juga lebih tinggi dibandibandingkan dengan baja tulangan. Kuat tarik merupakan gaya yang sangat dominan dalam kapal. Hal dapat dilihat pada saat kapal pada posisi hogging dan sagging.

Laminasi bambu juga mempunyai kekuatan pukul (impact) yang lebih tinggi (46.78 \%) dibandingkan dengan laminasi kayu maupun kayu jati. Kekuatan pukul ini seperti kejadian pada kapal saat terjadi hantaman gelombang maupun saat kapal menerjang benda keras ditengah lautan seperti balok kayu dan juga benturan-benturan pada saat kapal sandar.

- Penurunan kekuatan lentur statik laminasi bambu dengan adanya buku bambu rata-rata $9.21 \%$ (4.36 \% - $13.88 \%)$ pada konstruksi lamisi dengan jumlah lapisan yang berbeda. Walaupun terjadi penurunan kekuatan lentur statik pada laminasi bambu, kekuatan lentru statik laminasi bambu yang mengandung buku $(702.41 \mathrm{~N} / \mathrm{mm} 2)$ masih lebih baik dibandingkan dengan kekuatan lentur statik kayu jati solid $(620.64 \mathrm{~N} / \mathrm{mm} 2)$.

Demikian juga pengaruh buku bambu pada konstruksi laminasi terhadap kuat tarik terjadi penurunan rata-2 $10.44 \quad \% \quad(8.69 \quad \%$ $13.72 \%)$. Dan kuat tarik pada laminasi bambu yang mengandung bambu mengalami penurunan sebesar $8.69 \%$, kuat tari bambu laminasi dengan buku bambu (2311.74 $\mathrm{N} / \mathrm{mm} 2$ ) masih lebih tinggi dibandingkan dengan kuat tarik kayu jati $(696.20 \mathrm{~N} / \mathrm{mm} 2)$

Jumlah lapisan (number of layer) dalam konstruksi laminasi mampu menaikkan kuat lentur statik dan kuat tarik hingga $46.34 \%$. Bahkan konstruksi laminasi pada bambu (bambu laminasi) peningkatan kekuatan tariknya hingga mencapai $99 \%$ pada laminasi yang mengandung buku. Sehingga dapat dikatakan bahwa buku bambu dalam kondisi berdiri sendiri mempunyai pengaruh yang sangat besar. Tetapi pengaruh buku bambu menjadi lebih kecil apabila berada 
dalam konstruksi laminasi atau laminasi bambu.

- Laminasi Bambu mempunyai ketahanan terhadap beban dinamis lebih baik dibandingkan dengan kayu jati dan laminasi kayu jati-bambu. Penurunan kekuatan yang dialami oleh laminasi bambu setelah menerima beban dimamis relatif lebih kecil dibandingkan dengan kayu jati dan laminasi kayu jatibambu. Setelah menerima beban yang berulang-ulang (repeated loading), laminasi bambu masih mempunyai kuat tarik paling tinggi dan mengalami penurunan kekuatan sekitar $23.20 \%$, sedangkan kayu jati yang merupakan bahan pembangunan kapal kayu mengalami penurunan kekuatan mencapai $63.26 \%$. Sehingga diantara material kayu jati, komposit kayu bambu dan laminasi bambu, ternyata laminasi bambu mempunyai ketahanan terhadap beban dinamis yang paling baik. Dalam konstruksi kapal kayu, material yang mempunyai endurance limit tinggi merupakan persyaratan utama dalam pemilihan material.

\section{PUSTAKA.}

1985. The Gougeon Brothers on Boat

Construction. Wood \& West System*

Materials (New Revised, Fourth Edition).

Trademark of Gougeon Brothers. Inc. USA.

Amada S, Ichikawa Y, Munelata, Nagase Y and Shimizu H. 1996. Fiber Texture and Mechanical Graded Structure of Bamboo. Dep. of Mechaniccal Engineering, Gumme University. Japan.

American Standard for Materials and Testing, Designation : D 143-83 (1994) : Standard Methods of Testing Small Clear Specimens of Timber. Annual Book of ASTM Standards. Section 4 (Constriction) Volume 04.10 Wood. Philadelphiaq. PA.

Anonim (1979). Technical Notes Aerodux in the Thames Barrier. Plastics Division, CIBA GEIGY Plastics and Additives Company. England.

ASTM D-3479. 1988. Standard Test Methods for Tension-tension Fatigue or oriented Fiber, Resin Matrix Composites. In Annual Book of ASTM Standards, Fakultas Teknik Universitas Pattimura, ISSN : 2620-3995
American Society for Testing and Materials, Philadelphia.

ASTM E-1150. 1988. Standard Definitions of Terms Relating to Fatigue. In Annual Book of ASTM Standards, American Society for Testing and Materials, Philadelphia.

ASTM E-739. 1988. Standard Practice for Statistical Analysis of Linier or Linearized Stress-Life (S-N) and StrainLife (.-N) Fatigue Data. In Annual Book of ASTM Standards, American Society for Testing and $<$ aterials, Philadelphia.

ASTM E-740. 1988. Standard Practice for Fracture Testing With Surface-Crack Tension Specimens. In Annual Book of ASTM Standards, American Society for Testing and Materials, Philadelphia.

Badan Penelitian dan Penerapan Teknologi. 1994. Upaya Memenuhi Kebutuhan Kapal Perikanan. Deputy Bidang Pengkajian Industri. Jakarta

Biro Klasifikasi Indonesia (1996) Peraturan Konstruksi dan Pembangunan Kapal Kapal Kayu.

Bodiq, J and Benyamin AJ. 1982. Mechanics of Wood and Wood Composites. Nostrand Reinhold Company.

British Standards Institution (BS) 1204 : Part 2 (1965). Specification for Syintetic Resin Adhesives (Phenolic and Aminoplastic) for Wood. British Standard House, 2 Park ST. London.

Broek, D. 1989. The Practical Use of Fracture Mechanics. Kluwer Academic Publisher Incorporates. Nederlands.

China National Bamboo Research Centre, 2001. Cultivation and Integrated Utilization on Bamboo in China. Hangzhou. China.

Chugg, WA. 1964. The Manufacture of Glue Laminated Structurer. Ernest Benn Limited, London.

Clough, RW and Joseph Penzien. 1993. Dynamics of Structrures (Second Edition). University of California, Berkeley and International Cicil Engineering Consultants, Inc. McGrawHill Inc. New York. 
Coolins, JA. 1981. Failure of Materials in Mechanical Design. John Willey and Sons. New York.

Cronk. K, Kent. J, Maji, D and Walstad W. 2004. Cyclic Testing of Wooden Material.

Douglass C. Montgomery. 1997. Design and Analysis of Experimental. John Wiley and Sons.

Fangchun, Z. 2000. Selected Works of Bamboo Research. The Bamboo Research Editorial Committee, Nanjing Forestry University, Nanjing, China.

Ghavami. K. 1995. Ultimate Load Behaviour of Bamboo-Reinforced Lightweight Concrete Beams. Civil Engineering Department, PUC-Rio, Rio De Janero, Brazil.

Karnasudirdja, S. 1979. Tegangan dasar Beberapa Jenis kayu Indonesia (Basic Stresses of Some Indonesian Timber Species). Laporan no.140. Lembaga Penelitian Hasil Hutan. Badan penelitian dan pengembangan Pertanian. Departemen Pertanian. Bogor.

Keitth, F and Thomas GW. 1999. Wood Engineering and Construction Handbook 3rd edition. MicGraw Hill. Inc. New York.

Koch, P and GE Woodson, 1968. Laminating Butt-jointed Log-run Southern Pine Veneer into Long Beams of High Strength. Forest Product Journal. 18(10) : 45-57.

Krisdianto, Sumarni G dan Ismanto A. 2000. Sari Hasil Penelitian Bambu. Pusat Penelitian Hasil Hutan. Bogor.

Kunesh RH, 1978. Micro-Lam : Structural Laminated Veneer Lumber. Forest Product Journal 28(7) : 41-44.

Launfenberg TL, 1983. Parallel-Laminated Veneer : Processing and Performance Research Review. Forest Product Journal. 33(9) : 21-28.

Logan, DL. 1988. Mechanics of Materials. Rose-Hulman Institute of Technology. Harper Collins Publisher. New York.

Martawidjaja, A. 1978. Kayu untuk Industri Perkapalan di Indonesia. Timber Used for the Shipbuilding Industry in Indonesia.
Bagian I. Laporan Penelitian Hasil Hutan. Badan penelitian dan Pengembangan Pertanian. Departemen pertanian. Bogor.

Morisco. 1999. Rekayasa Bambu. Jurusan Teknik Sipil. PAU Universitas Gajah Mada. Yogyakarta.

Nan Feng. 2005. Behaviour of Wood, Under Static and Cyclic Shear Stress. Faculty of Forestry and Environmental Management, University of New Brunswick.

Penny, DT. 1977. Fracture Mechanics Analysis of Butt Joints in Laminated Wood Beams. Master's Thesis, Colorado State University, Ford Collins, CO.

Pizzi A. 1983. Wood Adhesives, Chemistry and Technology. Marcel Dekker Inc. New York.

Popov, EP. 1976. Mechanics of Materials (second edition). Prentice Hall. New Jersey.

Rosyid DM dan Widodo, AB. 2001. Riset Unggulan Kemitraan (RUK) VI tahun 2000. Pengembangan Material Konstruksi Laminasi untuk Aplikasi Kelautan. Kerjasama antara ITS dengan PT. PAL dan PT. Pamolite Adhesive Industry. Surabaya.

Saito, S dan Surdia, T. 2000. Pengetahuan Bahan Teknik. Program Studi Teknik Produksi dan Metalurgi. Jurusan Mesin. Institut Teknologi Bandung (ITB). PT. Pradnya Paramita. Jakarta.

Seward D. 1994. Understanding Structure. Analysis, Materials, Design. Department of Engineering of Lancaster. London.

Siswantoyo. 1990. Manajemen Hutan, Organisasi dan Tata Laksana Pengusahaan Hutan. Yayasan Pembina Fakultas Kehutanan. Universitas Gadjah Mada. Yogyakarta.

Smith. I, Landis. E and Gong, M. 2003. Fracture and Fatigue in Wood. American Institute of Timber Construction (AITC). New York.

Subianto. B, Subiyakto, Prasetyo. B dan Sudiono, 1996. Pengembangan Papan bambu LAMINASI. Laboratorium Bahan LAMINASI Puslitbang Fisika TerapanLIPI, Puspitek Serpong. Tangerang. 
Surjonokusuma, S dan Nugroho, N. 1997. Pemanfaatan Bambu sebagai Bahan Bangunan. Jurusan Teknologi Hasil Hutan, Fakultas Kehutanan, IPB. Bogor.

US Forest Product Laboratory. 1987. Wood Handbook. US Department of Agriculture Handbook 72. US Government Printing Office. Washington DC.

Widjaja. S dan Widodo AB. 2004. Karakterisasi Struktur Kapal Kayu dengan Material Alternatif LAMINASI Bambu. Laporan Hasil Akhir Pelaksanaan Penelitian Hibah Bersaing XII (2004-2005) Institut Teknologi Sepuluh Nopember (ITS). Surabaya

Widodo, AB et al (1996). Pemanfaatan papan Non Radial (Non Quarter Sawn) Sebagai Bahan Alternatif Dalam Pembangunan Kapal Kayu Dengan Sistem Lapisan Ganda (Double Layers). Departemen Penelitian dan Pengembangan, Divisi Teknologi, PT. PAL INDONESIA (PERSERO), Surabaya.
Widodo. AB. 1994. LVL for Deck and Sheel Planking on the Wooden Boat Construction. Master Thesis in Wood Science and Technology. Div. of Forest Science Faculty of Agriculture. Tokyo University of Agriculture. Tokyo, Japan.

Widodo, AB. 2014. Rancang Bangun Kapal Ikan Ukuran 5 Gross Tonnage (GT) Dengan Menggunakan Material Utama Komposit Bambu Untuk Memenuhi Penyediaan Kapal Penangkap Ikan Secara Nasional. Laporan Akhir Pelaksanaan Penelitian Riset Andalan Perguruan Tinggi dan Industri (RAPID). Kementerian Riset, Teknologi dan Perguruan Tinggi.

Williamson TG. 2002. APA Engineered Wood Handbook. McGraw-Hill. London. 